\title{
Identification of Class 1 Integron of Escherichia coli from Street Foods in Jakarta
}

\author{
FRISCA, BIBIANA WIDYATI LAY, AND DIANA ELIZABETH WATURANGI* \\ Faculty of Biotechnology, Universitas Katolik Indonesia Atma Jaya, \\ Jalan Jenderal Sudirman 51, Jakarta 12930, Indonesia
}

\begin{abstract}
A total of 43 Escherichia coli isolates were identified from school street foods located in Northern and Southern Jakarta. The isolates were examined for antibiotic resistance using five antibiotics discs (ampicillin, kanamycin, streptomycin, trimethoprim, tetracycline) and screened for the class 1 integron with specific conserved region primer using PCR amplification. The antibiotic diffusion test revealed three isolates (7\%) with resistance to multiple antibiotics. PCR detection of integron regions showed one isolate possessed a class 1 integron bearing one gene cassette with $\sim 700 \mathrm{bp}$ amplicon size. DNA sequencing showed that the gene cassette was resistant to trimethoprim determinant type $V(\mathrm{dhfrV})$. The integron bearing $E$. coli strain could become a threat for the widespread distribution of an antibiotic resistance gene especially for pathogenic bacteria.
\end{abstract}

Key words: Escherichia coli, street foods, antibiotic, integron

Poor sanitation of school's street foods (that are obtained from street vendors outside schools), which is commonly found in Indonesia, may lead to the disease that could risk millions of children health. Therefore, Escherichia coli is an important food hygiene indicator to access the quality of street foods. The presence of $E$. coli also shows the probability of contamination by enteric pathogenic bacteria, like Salmonella sp., Vibrio sp., or Enteropathogenic E. coli (EPEC) (Stiles and King 1981).

Resistance to antibiotics is highly prevalent in bacterial isolates worldwide, particularly in developing countries (Okeke et al. 2000). Normal intestinal microbiota, including E. coli, usually act as a reservoir for resistance determinants. They are often associated with mobile genetic vectors like plasmids, transposons, and integrons.

Integrons are gene acquisition and expression systems formed via site specific recombination. The units of DNA captured by integrons are termed gene cassettes. Gene cassettes are DNA mobile elements composed of a gene, most commonly encoding antibiotic resistance, and an integrase specific recombination site known as 59-base element (59be) (Stokes et al. 2001). Four types of integron have been identified to date according to homology sequences of their integrase genes, of which the class 1 integron is the most prevalent among clinical isolates, especially Enterobacteriaceae (Chang et al. 2000). More than 60 distinct cassettes have been shown to be carried within the class 1 integron.

The aim of our study was to search for the presence of the class 1 integron in E. coli isolated from street foods and to characterize their gene cassette assortments. The finding of an integron could become a threat for creating widespread antibiotic resistance genes especially in pathogenic bacteria.

${ }^{*}$ Corresponding author, Phone: +62-21-5703306 ext 335, Fax: +62-21-5719060, E-mail: diana.waturangi@atmajaya.ac.id

\section{MATERIALS AND METHODS}

Collection of Samples. A total of 20 foodstuffs and beverages samples were collected from vendors outside five elementary schools in Northern and Southern Jakarta respectively. Two kinds of foods and beverages which were those commonly consumed by children, were taken from each location. Street food samples obtained were immediately placed in a cooler box during transportation to the laboratory. Samples were collected from July through to August 2005.

Isolation of Bacteria. Food samples were blended and weighted aseptically. An amount of $25 \mathrm{~g}$ of blended food sample was added to $250 \mathrm{ml}$ of tryptone soya broth medium and then incubated for 3 hours at $37^{\circ} \mathrm{C}$. Beverages samples (250-300 ml) were aseptically filtered using a micro-filter vacuum pump containing a $0.2 \mu \mathrm{m}$ filter membrane (Millipore). The filter membrane was then added to $50 \mathrm{ml}$ of tryptone soya broth and incubated at $37^{\circ} \mathrm{C}$. Serial dilution $\left(10^{-4}-10^{-6}\right)$ was made from the inoculated broths and immediately subcultured to Eosin Methylene Blue agar (EMB).

Identification of $\boldsymbol{E}$. coli. Identification used biochemical tests, Triple Sugar Iron Agar (TSIA), IMViC (Indole, Methyl Red, Voges Proskauer, Citrate), and MUG (4methylumbelliferyl- $\beta$-D-glucuronide) according to SNI 012332-1991.

Antibiotic Resistance Test (Agar Diffusion). A susceptibility test to 5 antibiotics which are frequently used in therapy, and commonly found in gene cassette form, was tested using the disc diffusion method on Mueller Hinton Agar. Those antibiotics were ampicilin $(10 \mu \mathrm{g})$; kanamycin $(30 \mu \mathrm{g})$; streptomycin $(10 \mu \mathrm{g})$; trimethoprim $(5 \mu \mathrm{g})$; and tetracycline $(30 \mu \mathrm{g})(\mathrm{OXOID}$, Hampshire, England). The susceptibility tests were interpreted according to document M100-S9 (WHO 1999).

Detection of Class 1 Integron. Whole-cell DNA of all 43 E. coli isolates, were screened for the presence of class 1 integron using PCR amplification (Perkin Elmer, USA) according to the procedure of Lavesque et al. (1995). Specific conserved class 1 integron region primers, $5^{\prime} \mathrm{CS}$ (5'-GGCA 
TCCAAGCAGCAAG-3') and 3'CS (5'- AAGCAGACTT GACCTGA-3') (Proligo) were used to amplify any integrated gene cassettes. E. coli obtained from Varanus spp. feces (Waturangi et al. 2003) was used as positive control. The PCR product was separated by agarose gel electrophoresis and purified using Qiaquick gel extraction kit (Qiagen). The PCR product was sequenced by using Big Dye $\AA$ Terminator v3.1 Cycle Seuencing Kit (Applied Biosystems USA). The product was analyzed with an ABI Prism 377 Automated DNA Sequencer. For comparison with known sequences, the Basic Local Allignment Search Tool (BLAST) computer search program was used.

Nucleotide Sequence Accession Number. The nucleotide sequence data reported in this paper will appear in the GenBank nucleotide database under the accession number DQ520731.

\section{RESULTS}

A total number of 69 bacteria isolates were collected from street food samples in North and South Jakarta, from which 21 isolates were obtained from food samples while 48 other isolates came from beverages. Thirteen isolates from foods and 30 isolates from beverages, showed biochemical characteristics of $E$. coli. The characteristics gave ++-- results of IMViC tests and positive MUG according to SNI 01-23321991.

Escherichia coli contamination was not found in food samples from Northern Jakarta while $20 \%$ of food samples from Southern Jakarta were contaminated. Some 50\% of Northern Jakarta beverage samples and 40\% from Southern Jakarta were contaminated with $E$. coli.

The highest level of antibiotic resistance, from the 43 $E$. coli isolates attained, were found toward tetracycline $(11.6 \%)$. On the contrary, none of the E. coli isolates was found to be resistant to kanamycin. Some $4.7 \%$ of total isolates showed resistance to each of ampicillin, streptomycin, and trimethoprim (Figure 1).

PCR detection of class 1 integron showed one isolate (coded FC12A) from Northern Jakarta beverage sample, possessed class 1 integron bearing one gene cassette with $\sim 700$ bp of amplicon size (Figure 2). DNA sequencing showed that the gene cassette was resistant to trimethoprim determinant type $\mathrm{V}(\mathrm{d} h f r V)$ (Figure 3).

\section{DISCUSSION}

A total of $43 \mathrm{E}$. coli isolates from street foods were identified based on their biochemical characteristics. Those isolates showed similar phenotypes and were categorized as variety-1 E. coli based on their IMViC tests results ++-according to SNI 01-2332-1991.

In this study, two areas of sampling, Northern Jakarta which has poor sanitation was compared to Southern Jakarta. The results showed there was no significant difference between the percentages of the E. coli present in street food samples from Northern Jakarta and Southern Jakarta. This information indicated that the level of hygiene of street foods samples from Southern Jakarta was not better than those from Northern Jakarta. The presence of $E$. coli shown in this
Table 1 Percentage of contaminated food samples in Northern and Southern Jakarta

\begin{tabular}{lcc}
\hline Location & Contaminated food (\%) & Not contaminated food (\%) \\
\hline North Jakarta & 50 & 50 \\
South Jakarta & 40 & 60 \\
\hline
\end{tabular}

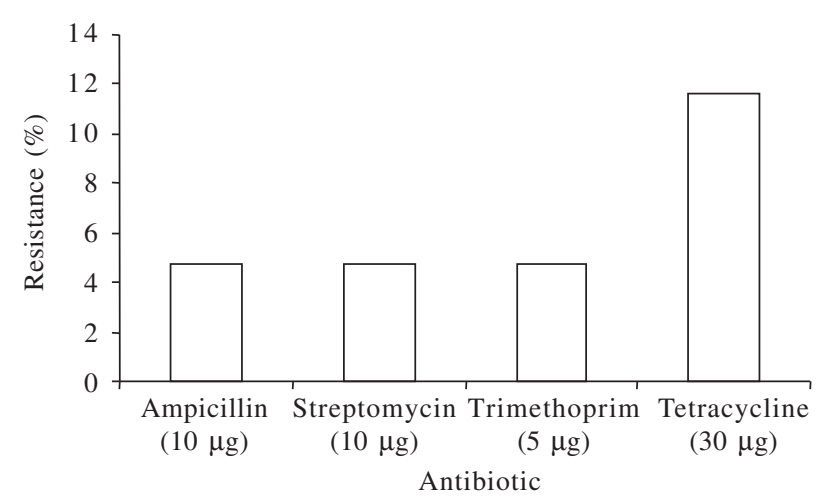

Figure 1 Measurement of resistance by diffusion agar method.

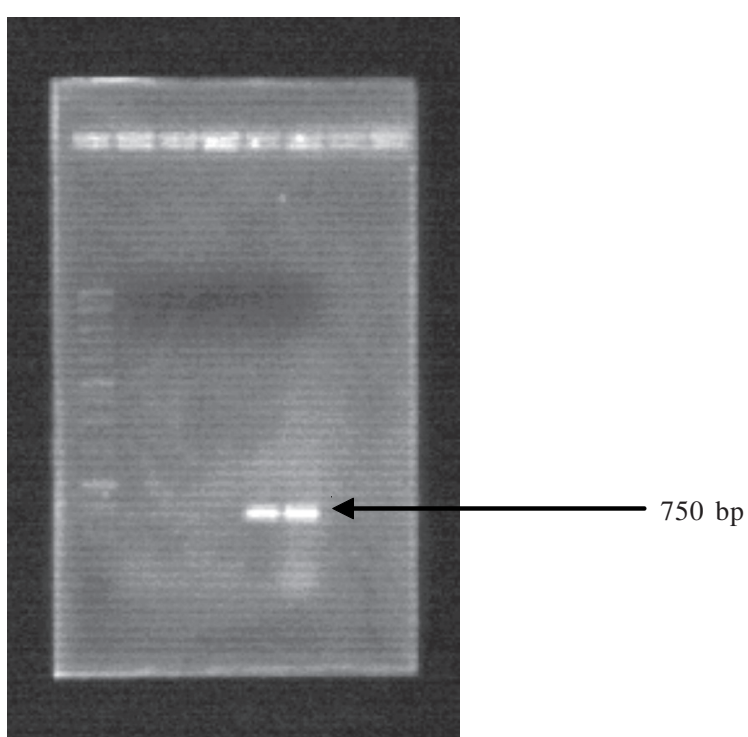

Figure 2 DNA electrophoresis of PCR amplification using specific conserved region class 1 integron $\left(5^{\prime} \mathrm{CS}\right.$ and $\left.3^{\prime} \mathrm{CS}\right)$ primer in $1 \%$ $(\mathrm{w} / \mathrm{v})$ agarose gel. Well 1 contained DNA marker (1 kb ladder); well 5 contained positive control (PCR amplicon from E. coli origin of Varanus spp.), and well 6 contained PCR amplicon from FC12A isolate $(750 \mathrm{bp})$.

study is an important public health issue, especially for elementary school students in Northern and in Southern Jakarta. The presence of E. coli in beverage samples is particulary noteworthy because the acceptable standard for E. coli in drinking water is 0 per $100 \mathrm{ml}$ according to international and national regulations (WHO 1982).

The antibiotic diffusion test revealed five isolates from a total of total 43 E. coli isolates (11.6\%) from beverage samples resistant to at least one of 5 antibiotics tested. Moreover, 3 isolates were resistant to multiple antibiotics i.e. the isolates were resistant to all of antibiotics tested except kanamycin. The resistant strains could be present in beverage samples via contamination from animal or human feces in beverage ingredients (especially water) which have been exposed to antibiotics and then contaminated by the street vendors. The incidence of resistance to ampicillin, streptomycin, tetracycline, and trimethoprim in E. coli supports the findings 


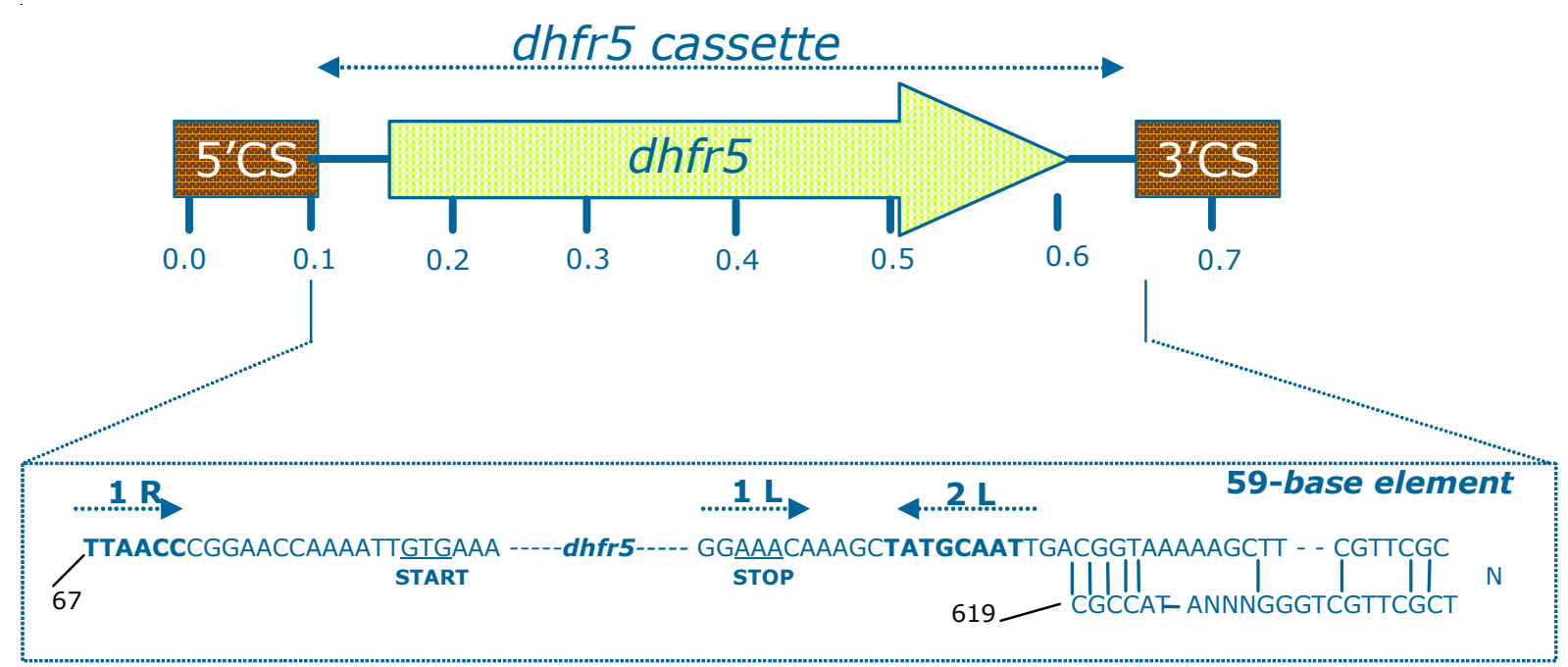

Figure 3 Characterization of gene cassette structure (dhfr5) which is integrated in the class 1 integron FC12A. Open Reading Frame $d h f r 5$ gene was shown in box. Start and stop translation codon were underlined. Putative 59 be region, 1R, $1 \mathrm{~L}$, and $2 \mathrm{~L}$ for integrase binding domains were shown with arrows.

of other studies on antimicrobial agent resistance of E. coli from different sources throughout the world (Okeke et al. 2000; Schroeder et al. 2002; Roe et al. 2003; Sayah et al. 2005).

The highest levels of resistance were observed for tetracycline $(11.6 \%)$ while resistance to ampicillin, streptomycin, and trimethoprim showed the same percentage $(4.7 \%)$. Therefore, these isolates may play a key role as an acceptor and donor of transmissible antimicrobial resistance mechanisms. This is a matter of concern since the indiscriminate use of antibiotics, along with poor hygiene and inadequate infection control (risk factors for antibiotic resistance in bacteria) are highly prevalent in developing countries, including Indonesia (Okeke et al. 2000; Tjaniadi et al. 2003).

Tetracycline, a first line broad spectrum antibiotic, has been used extensively worldwide in therapy in animals and humans since 1940 (Walsh 2003). The high level of prevalence of resistance to tetracycline may be due to widespread and lengthy use of tetracycline considering its easy use orally and the low human toxicity of this antibiotic. In addition, tetracycline is a naturally derived compound; bacteria can be exposed to these agents in nature and outside of normal human use e.g. for treatment of livestock to promote growth rates (Sayah et al. 2005).

The existence of $E$. coli with low levels of resistance toward the antibiotics indicated that most of the E. coli strains were susceptible. Street foodstuffs, which are not intentionally exposed to large of quantities of antibiotics, exhibited a significantly lower prevalence of antibiotic resistance than from other sources, e.g. human's gut or feces, as studied by Mulyastuti (1996). This is consistent with the hypothesis that exposure of commensal gut microbiota to antibiotics selects for resistant bacterial strains (Sayah et al. 2005). Susceptibility to five antibiotics by most of the $E$. coli isolates examined, indicates that the antibiotics are still effective for use in treatment of diarrhea, which is commonly caused by this pathogenic bacterium.
PCR detection of a class 1 integron from 43 E. coli isolates revealed one isolate (coded FC12A), from Northern Jakarta, yielded an amplicon $\sim 700$ bp in size. Sequence analysis showed that this amplicon contained a dhfr 5 gene cassette for trimethoprim resistance. The predicted product of the $d h f r 5$ reading frame comprised 157 amino acids and proved to be identical (100\%) to the type 5 dihydrofolate reductase protein (DHFR5) (E. C. 1.5.1.3) according to the study of E. coli from India (accession no. AJ620333.1) by Mukherjee and Chakraborty (2006). Waturangi et al. (2003) also found the $d h f r 5$ gene cassette in a class 1 integron from E. coli isolated from Indonesian Varanus spp.

Finding the class 1 integron bearing a trimethoprim resistance determinant gene cassette in this study supports the report of Adrian et al. (1999). This showed that the gene cassettes which are commonly found integrating in the class 1 integron coded for resistance to trimethoprim and aminoglycoside antibiotics. The extensively use of trimethoprim and sulfonamide in combination since 1968 might select for the $d h f r$ gene cassette obtained here and explain the emergence of trimethoprim resistance which is linked to the class 1 integron.

Antibiotic resistance could be mediated by a plasmid, a transposon, a cassette integrated in an integron, or by chromosomal mutation (Huovinen et al. 1995). In this study, resistance to trimethoprim in FC12A which is encoded by the $\operatorname{dhfr} 5$ gene, was integrated as a gene in the class 1 integron. The other resistant isolates might be linked to other classes of integron. This study suggests that an integronbearing E. coli strain could be present in contaminated street food. This finding could potentially play a role in the transfer of antibiotic resistance genes to other human microbiota because $E$. coli is a commensal bacteria in the human intestine. This sounds a warning because the class 1 integron bearing E. coli, which was found in this study, could become a threat for widespread distribution of antibiotic resistance in pathogenic bacteria. 


\section{ACKNOWLEDGMENT}

This research was part of the Jakarta in Focus Project funded by the Research Institute of Universitas Katolik Indonesia Atma Jaya, Jakarta, Indonesia.

\section{REFERENCES}

Adrian PV, Thomson CJ, Klugman KP, Amyes SGB. 1999. New gene cassettes for trimethoprim resistance, $d f r 13$, and streptomycinspectinomycin resistance, aadA4, inserted on a class 1 integron. Antimicrob Agents Chemo 44:355-361.

Chang CY et al. 2000. Two new gene cassettes, drfl7 (for trimethoprim resistance) and aadA4 (for spectinomycin/ streptomycin resistance), inserted in an Escherichia coli class 1 integron. J Antimicrob Chemo 46:87-89.

Huovinen P, Sundstrom L, Swedberg G, Skold O. 1995. Trimethoprim and sulfonamide resistance. Antimicrob Agents Chemo 39:279289.

Mukherjee S, Chakraborty R. 2006. Incidence of class 1 integrons in multiple antibiotic-resistant Gram-negative copiotrophic bacteria from the River Torsa in India. J Res Microbiol 157:220-226.

Mulyastuti T. 1996. Perbedaan Profil Kekebalan Bakteri Flora Usus pada Pengambilan Sampel Satu, Tiga, dan Lima Strain, Setiap Tinja [Lap Pen]. Surabaya: Fakultas Kedokteran, Universitas Airlangga.

[NCCLS] National Committee for Clinical Laboratory Standards. 1999. Performance standards for antimicrobial susceptibility testing; ninth informational supplement. Wayne, Pennsyslvania: NCCLS. document M100-S9, Vol. 19. No. 1, Table 2I.

Okeke IN, Fayinka ST, Lamikanra A. 2000. Antibiotic resistance in Escherichia coli from Nigerian students, 1986-1998. Emerg Infect Dis 6:393-396.
Roe MT, Vega E, Pillai SD. 2003. Antimicrobial resistance markers of class 1 and class 2 integron-bearing Escherichia coli from irrigation water and sediments. Emerg Infect Dis 9:822-826.

Sayah RS, Kaneene JB, Johnson Y, Miller RA. 2005. Patterns of antimicrobial resistance observed in Escherichia coli isolates obtained from domestic- and wild-animal fecal samples, human septage, and surface water. Appl Environ Microbiol 71:13941404.

Schroeder CM et al. 2002. Antimicrobial resistance of Escherichia coli $\mathrm{O} 26, \mathrm{O} 103$, O111, O128, and $\mathrm{O} 145$ from animals and humans. Emerg Infect Dis 8:1406-1414.

Stiles ME, King LN. 1981. Biochemical characteristics and identification of Enterobacteriaceae isolated from meats. Appl Environ Microbiol 41:639-645.

Stokes HW et al. 2001. Gene cassette PCR: sequence-independent recovery of entire genes from environmental DNA. Appl Environ Microbiol 67:5240-5246.

Tjaniadi $\mathrm{P}$ et al. 2003. Antimicrobial resistance of bacterial pathogens associated with diarrheal patients in Indonesia. Am J Trop Med Hyg 68:666-670.

Walsh C. 2003. Antibiotics Actions, Origins, Resistance. Washington DC: ASM Pr.

Waturangi DE, Suwanto A, Schwarz S, Erdelen W. 2003. Identification of class 1 integron-associated gene cassettes in Escherichia coli isolated from Varanus spp. in Indonesia. J Antimicrob Chemo 51:175-177.

[WHO] World Health Organization. 1982. Bacteriological examination in: Examination of Water Pollution Control. New Work: Academy Pr.

[WHO] World Health Organization. 1999. Laboratory methods for the diagnosis of epidemic dysentery and cholera. Document no. M100-S9 WHO/CDS/CSR/EDC/99.8. 
